\title{
A Case Report of Porokeratosis Ptychotropica in a Chinese Man
}

\author{
Xinjia Ou ${ }^{1, *}$ \\ Ping Wang ${ }^{2, *}$ \\ Wentao Chen ${ }^{3}$ \\ Weiwei $\mathrm{Wu} \mathbb{D D}^{2}$ \\ Jiejie $L^{2}{ }^{2}$ \\ 'Department of Dermatology, Hainan \\ Wanning People's Hospital, Wanning, \\ Hainan, People's Republic of China; \\ ${ }^{2}$ Department of Dermatology, The Fifth \\ People's Hospital of Hainan Province, \\ Branch of National Clinical Research \\ Center for Skin and Immune Disease, \\ Haikou, Hainan, People's Republic of \\ China; ${ }^{3}$ Department of Dermatology, \\ Hainan Provincial Anning Hospital, \\ Haikou, Hainan, People's Republic of \\ China
}

*These authors contributed equally to this work
Correspondence: Jiejie Lu

Department of Dermatology, The Fifth People's Hospital of Hainan Province, Branch of National Clinical Research Center for Skin and Immune Disease, No. 33, Southern Road of Longkun, Qiongshan District, Haikou, 570206, Hainan, People's Republic of China

Tel +86-13519816255

Fax +86-898-66729550

Email lujiejie677@I63.com

\begin{abstract}
Porokeratosis ptychotropica is a rare form of porokeratosis characterized by dyskeratotic skin lesions around genital area or gluteal cleft. Herein, a case of porokeratosis ptychotropica was reported. The patient was a 35-year-old man, who complained of pruritic papules and plaques in the perianal and buttock region for thirteen years. On examination, well-demarcated brown plaques with a verrucous white surface and multiple satellite papules were located along the gluteal folds and buttocks sparing the anus. Histopathological examination was consistent with porokeratosis. Combined with clinical manifestations and histopathologic changes, the patient was diagnosed as porokeratosis ptychotropica. He was treated with oral acitretin $30 \mathrm{mg} / \mathrm{d}$ and $\mathrm{CO}_{2}$ laser treatment, but the lesions showed no evident improvement after three months. Although it is not a new case, this condition is an extremely rare one that must be reviewed and emphasized. The dermatologist should keep porokeratosis ptychotropica in mind as one differential diagnosis for pruritic papules in the anogenital region.
\end{abstract}

Keywords: porokeratosis, intergluteal cleft, buttock

\section{Introduction}

Porokeratosis is a group of uncommon cutaneous disorders of epidermal keratinization with the characteristic histological feature of cornoid lamella in the upper area of invaginated epidermis. Although the etiology has not been completely elucidated, it has been reported that the development of sporadic porokeratosis can occur in the setting of immunosuppression and immunodeficiency. ${ }^{1}$ Porokeratosis ptychotropica is a rare form of porokeratosis first described by Lucker et al in 1995, where the dyskeratotic skin lesions are mainly located around the genital area or gluteal cleft. $^{2}$ In the present case, we reported a rare case of porokeratosis ptychotropica on the perianal and buttock region in a Chinese man. Although it is not a new case, this condition is an extremely rare one that must be reviewed and emphasized. The dermatologist should keep porokeratosis ptychotropica in mind as one differential diagnosis for pruritic papules in the anogenital region.

\section{Case Presentation}

A 35-year-old man visited our department with pruritic papules and plaques in the perianal and buttock region. The patient started to notice scattered red or dark brown papules on his perianal region thirteen years ago. In the past few years, the lesions aggravated and coalesced into verrucous plaques, and the buttocks were involved too. The patient complained of frequent and severe itching. Initially being 

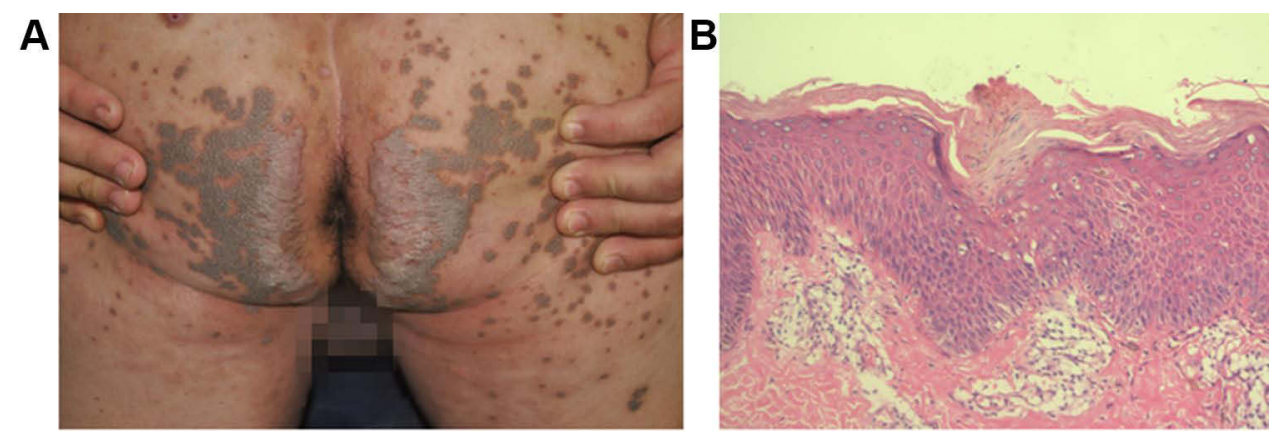

Figure I Clinical manifestation and histopathological findings of porokeratosis ptychotropica. (A) Clinical manifestation shows "Butterfly shaped" verrucous plaque over buttocks with multiple satellite papules. (B) Histopathological findings shows characteristic multiple cornoid lamellae. Dyskeratotic cells and focal hypogranulosis were present in the epidermis underlying the column of parakeratosis (H\&E staining, $\times 200$ ).

diagnosed with neurodermatitis or lichen planus, the patient was treated with different topical treatments including glucocorticoid ointment, retinoic acid ointment or salicylic acid ointment. However, the lesions continued to progress slowly. The patient's past medical and family history was unremarkable.

On examination, well-demarcated brown plaques with a verrucous white surface and multiple satellite papules along the gluteal folds and buttocks sparing the anus were noted (Figure 1A). The rest of the examination was unremarkable. A skin biopsy on the buttocks was performed. Histopathological examination showed characteristic multiple cornoid lamellae. Dyskeratotic cells and focal hypogranulosis were present in the epidermis underlying the column of parakeratosis (Figure 1B). The clinical and pathologic findings were compatible with a diagnosis of porokeratosis ptychotropica. The patient subsequently underwent treatment with oral acitretin capsules $(30 \mathrm{mg} /$ d) and $\mathrm{CO}_{2}$ laser resurfacing for three months, while only a slight improvement was noted. He was subsequently lost follow-up.

The patient provided written informed permission to have any accompanying photos and case details published. The Hospital Ethics Committees of the Fifth People's Hospital of Hainan Province approved to publish the case details.

\section{Discussion}

Porokeratosis ptychotropica is characterized by symmetrical red-brown verrucous plaques localized on the perianal cleft and buttocks region, usually forming a butterfly-shaped appearance. The lesions tend to coalesce and expand centrally, with formation of small satellite lesions at the periphery. Porokeratosis ptychotropica is often misdiagnosed as viral warts, psoriasis, epidermal nevus, chronic eczema, dermatophytosis, candidiasis, cutaneous tuberculosis, squamous cell carcinoma, or condyloma acuminata. ${ }^{3}$ The diagnosis of porokeratosis ptychotropica should be considered when the lesions present as pruritus verrucous plaques on the buttock that have poorly responded to conventional treatments. Histopathological examination is particularly important for differential diagnosis. The cause of porokeratosis ptychotropica has not been elucidated, but it is considered a multifactorial disease of abnormal epidermal keratinization. ${ }^{4}$ Takiguchi et al reported the largest number of patients with verrucous porokeratosis of the gluteal cleft. The results suggested that men are more affected by porokeratosis ptychotropica than women (21 of 23 patients are male), and the age of symptom onset ranges from 15 to 84 years. ${ }^{5}$ Coexistence with other forms of porokeratosis has been reported in other several cases. ${ }^{6,7}$ Most reported cases have arisen sporadically; however, autosomal dominant mode of inheritance was reported in one family pedigree. ${ }^{5}$ The key pathological feature to differentiate porokeratosis ptychotropica from the classic cases is that the cornoid lamellae in porokeratosis ptychotropica can be seen throughout the lesion, while the cornoid lamellae are typically located at the periphery in other variants. ${ }^{8}$ The other histopathological features of porokeratosis ptychotropica are similar to other porokeratosis variants, including epidermal hyperkeratosis, multiple cornoid lamellae in the stratum corneum, focal hypogranulosis, and dyskeratotic cells underlying the column of parakeratosis. However, verrucous histopathological appearance with multiple cornoid lamellae has also been reported in other histotype of porokeratosis. ${ }^{9}$ Therefore, the diagnosis of porokeratosis ptychotropica requires the combination of clinical and pathological features. Transformation of porokeratosis ptychotropica into invasive squamous cell carcinoma has been reported in one patient. $^{10}$ Radiation was thought to 
contribute to the development of porokeratosis ptychotropica within the radiation field and, via downregulation of p16, the subsequent transformation into invasive squamous cell carcinoma. It is also possible that repeated irritation from scratching and/or colitis-associated diarrhea contributed to the malignant change. The treatment of porokeratosis ptychotropica includes keratolytics, 5-fluorouracil, imiquimod, calcipotriol, corticosteroids, cryotherapy, and lasers ${ }^{11}$ Temporary symptomatic improvement can be achieved through treatment, but often is followed by relapses.

\section{Conclusion}

Porokeratosis ptychotropica shares similar symptoms with many other skin diseases and misdiagnosis of porokeratosis ptychotropica is common because of its indistinctive symptoms and its rarity. Therefore, we are reporting this case to improve the awareness of porokeratosis ptychotropica among dermatologists and pathologists.

\section{Ethics Statement}

The publications of images were included with the patient's consent.

\section{Consent Statement}

Informed consent was provided by the patient for publication of the case.

\section{Funding}

This work was supported by the Construction Project of Hainan Province Clinical Medical Center.

\section{Disclosure}

Xinjia $\mathrm{Ou}$ and Ping Wang are co-first authors for this study. The authors have no conflicts of interest to declare.

\section{References}

1. Ferreira FR, Lessa PP, Alvarenga ML. Genitogluteal porokeratosis - case report. An Bras Dermatol. 2013;88(3):438-440. PMID: 23793197; PMCID: PMC3754380. doi:10.1590/ABD1806-4841.20131831

2. Lucker GP, Happle R, Steijlen PM. An unusual case of porokeratosis involving the natal cleft: porokeratosis ptychotropica? $\mathrm{Br} J$ Dermatol. 1995;132(1):150-151. doi:10.1111/j.1365-2133.1995.tb08643.x

3. Contreras-Ruiz J, Toussaint-Caire S, Torres-Camacho $\mathrm{P}$, et al. Porokeratosis ptychotropica: a diagnostic and therapeutic challenge. J Eur Acad Dermatol Venereol. 2018;32:e114-e115. doi:10.1111/ jdv. 14600

4. Yeo J, Winhoven S, Tallon B. Porokeratosis ptychotropica: a rare and evolving variant of porokeratosis. J Cutan Pathol. 2013;40:1042-1047. doi:10.1111/cup.12233

5. Takiguchi RH, White KP, White CR Jr., et al. Verrucous porokeratosis of the gluteal cleft (porokeratosis ptychotropica): a rare disorder easily misdiagnosed. J Cutan Pathol. 2010;37:802-807. doi:10.1111/ j.1600-0560.2009.01387.x

6. Ma Y, Li C, Wu J, et al. Coexistence of porokeratosis ptychotropica with porokeratosis of Mibelli in a Chinese man. Postepy Dermatol Alergol. 2015;32(4):307-309. doi:10.5114/pdia.2015.53324

7. Murase J, Gilliam AC. Disseminated superficial actinic porokeratosis co-existing with linear and verrucous porokeratosis in an elderly woman: update on the genetics and clinical expression of porokeratosis. $J$ Am Acad Dermatol. 2010;63(5):886-891. doi:10.1016/j.jaad.2009.07.038

8. Liu W, Liu JW, Ma DL. Porokeratosis Ptychotropica. JAMA Dermatol. 2019;155(7):845. doi:10.1001/jamadermatol.2019.0602

9. Di Prete M, Koch L, Cerroni L. Keratotic nodules and plaques on the lower extremities: answer. Am J Dermatopathol. 2020;42(8):613. doi:10.1097/DAD.0000000000001668

10. Mazori DR, Shvartsbeyn M, Meehan SA, Tarsis SL. Transformation of porokeratosis ptychotropica into invasive squamous cell carcinoma. Int J Dermatol. 2017;56:679-680. doi:10.1111/ijd.13575

11. Joshi R, Minni K. Genitogluteal porokeratosis: a clinical review. Clin Cosmet Investig Dermatol. 2018;11:219-229. doi:10.2147/CCID. S143085
Clinical, Cosmetic and Investigational Dermatology is an international, peer-reviewed, open access, online journal that focuses on the latest clinical and experimental research in all aspects of skin disease and cosmetic interventions. This journal is indexed on CAS.
The manuscript management system is completely online and includes a very quick and fair peer-review system, which is all easy to use. Visit http://www.dovepress.com/testimonials.php to read real quotes from published authors. 